Jurnal Akuntansi Bisnis, Vol. 19, No. 1, Maret 2021

ISSN 1412-775X (media cetak) | 2541-5204 (media online)

\title{
Kajian Perbandingan Pengungkapan Corporate Social Responsibility: Analisis Deskriptif pada Sektor Perusahaan Pertanian Perkebunan.
}

\author{
Nashirotun Nisa Nurharjanti ${ }^{1 *}$, Erma Setiawati ${ }^{2}$, Eni Kusumawati ${ }^{3}$, \\ Fatchan Achyani ${ }^{4}$ \\ 1,2,3,4 Universitas Muhammadiyah Surakarta \\ *Corresponding author email: nnn122@ums.ac.id
}

\begin{abstract}
Disclosure of Corporate Social Responsibility (CSR) reflects a company's concern for its surrounding environment. This study examines the level of CSR disclosure among companies in the plantation agriculture sector. The aim is to determine the level of CSR compliance presented in the Sustainability Report based on GRI standards. The results of this study indicate that PT. Astra Agro Lestari Tbk, PT Bukit Asam Tbk, PT. Eagle High Plantations Tbk, PT. London Sumatra Indonesia Tbk, PT. Sinar Mas Agro Resources \& Technology Tbk and PT. Sawit Sumbermas has been continuously disclosing CSR with GRI Standards even though there are a number of indicators in GRI Standards that have not been disclosed. However, the application of CSR disclosure has been done both internally and externally. Especially PT. Astra Agro Lestari Tbk, which has an average percentage of 2016-2018, has a record of 75\% which is included in the Applied Good category. Where the general disclosure compliance rate was 87.50\%, compliance in management approach $100 \%$, compliance in environment $96.67 \%$, and compliance in social $90.2 \%$
\end{abstract}

Keywords: GRI, sustainability report, disclosure compliance, CSR disclosure.

\begin{abstract}
Abstrak
Pengungkapan Corporate Social Responsibility (CSR) merupakan salah satu bentuk kepedulian terhadap lingkungan. Penelitin ini menganalisis tingkat pengungkapan CSR perusahaanperusahaan yang masuk dalam sektor pertanian perkebunan. Tujuan penelitian adalah menilai tingkat kepatuhan pengungkapan CSR berdasarkan standar GRI. Penelitian ini menggunakan analisis deskriptif. Hasil penelitian menunjukkan bahwa PT. Astra Agro Lestari Tbk, PT Bukit Asam Tbk, PT. Eagle High Plantations Tbk, PT. London Sumatra Indonesia Tbk, PT. Sinar Mas Agro Resources \& Technology Tbk dan PT. Sawit Sumbermas terus melakukan pengungkapan CSR dengan standar GRI meski ada sejumlah indikator dalam standar GRI yang belum diungkapkan. Namun penerapan pengungkapan CSR telah dilakukan baik secarainternal maupun eksternal. PT. Astra Agro Lestari Tbk yang memiliki persentase rata-rata tahun 2016-2018 mencatatkan rekor sebesar $75 \%$ yang termasuk dalam kategori baik. Dimana tingkat kepatuhan pengungkapan umum $87,50 \%$, kepatuhan dalam pendekatan manajemen $100 \%$, kepatuhan lingkungan $96,67 \%$, dan kepatuhan dalam sosial 90,2\%.
\end{abstract}

Kata kunci: GRI, laporan berkelanjutan, pengungkapan CSR, disclosure compliance.

\section{PENDAHULUAN}

Perhatian yang diberikan oleh perusahaan lembaga pemerintah badan-badan profesional dan kelompok lainnya terhadap isu keberlanjutan telah meningkat dengan cepat selama beberapa tahun 
terakhir (Bouten dan Everaert, 2014). Tuntutan pemerintah, media, aktivis dan masyarakat terhadap perusahaan dalam mengkalkulasi tanggungjawab dari aktivitas bisnis secara sosial dan lingkungan juga menjadikan perhatian. Selain itu beberapa yayasan dan lembaga memberikan peringkat terhadap kinerja tanggung jawab sosial perusahaan. Mekanisme yang dapat dilakukan perusahaan untuk meningkatkan kesadaran akan keberlanjutan adalah melakukan praktik pelaporan Corporate Sosial Responsibility (Bouten dan Everaert, 2014).

Konsep Corporate Social Responsibilty (CSR) saat ini menjadi suatu isu yang krusial dan tumbuh secara efektif dibeberapa perusahaan. Perkembangan pengungkapan CSR ini diikuti dengan pentingnya implementasi praktis dari pelaporan CSR. Implementasi CSRini dapat dilakukan oleh perusahaan dengan beberapa mekanisme. Pertama, pelaporan CSR yang bersifat berdiri sendiri dimana disamping perusahaan memberikan laporan kinerja dan investasi setiap tahun, perusahaan membuat laporan sendiri yang memberikan informasi tambahan kepada pemangku kepentingan (GRI, 2013). Laporan yang berdiri sendiri secara umum memberikan informasi terkait dengan pengungkapan sosial dan lingkungan perusahaan. Kedua, pelaporan CSR yang diverifikasi oleh pihak eksternal yang berupa assurance (jaminan). Hal ini sesuai dengan pernyataan Wong dan Milington (2014) adanya jaminan dari pihak eskternal dapat memperkokoh legitimasi perusahaan dalam mengungkapkan CSR.

Penelitian lain juga menyatakan bahwa jaminan merupakan salah satu metode yang dapat meningkatkan indikator kredibilitas perusahaan dalam pelaporan CSR (Casey dan Grenier, 2015; Cohen dan Simnett, 2015; Habek dan Wolniak, 2016). Pelaporan yang ketiga adalah menggunakan pedoman pelaporan Global Reporting Indeks (GRI). Kerangka pelaporan GRI dengan standarisasi internasional dikenal dengan pelaporan keberlanjutan (Bebbington et al., 2012; Gray, 2010; Mahoney, et al., 2013). Praktik pelaporan CSR secara sukarela yang dilakukan oleh perusahaan kemungkinan masih memberikan peluang untuk terjadi indikasi penyalahgunaan (Michelon et al., 2015). Kondisi ini kemungkinan terjadi karena adanya motivasi terkait legitimasi perusahaan. Metode yang digunakan perusahaan untuk memenuhi legitimasi bisa dilakukan secara substantif atau simbolis.

Mekanisme substantif dapat ditempuh perusahaan dengan adanya komitmen untuk peduli dan menjaga sosial dan lingkungan dari pengaruh negatif. Pengungkapan aktivitas CSR yang sering dilakukan mengindikasikan bahwa perusahaan memiliki komitmen yang kuat terhadap pekerja, sosial dan lingkungan (Hong and Andersen, 2011). Mekanisme simbolik dalam pengungkapan aktivitas CSR dapat dikategorikan sebagai kegiatan yangdilakukan hanya untuk memenuhi syarat ideal dengan tujuan untuk memperoleh legitimasi dari para pemangku kepentingan dengan tidak memperhatikan norma-norma sosial. Hal ini sesuai dengan pernyataan pengungkapan aktivitas CSR bisa menjadi alternatif untuk pencapaian tujuan perusahaan terkait citra perusahaan (Cho et al., 2012; Dobbs dan Staden, 2016; Hopwood, 2009; Merkl dan Brennan, 2007; Michelon et al., 2015).

Penelitian ini merespon GRI yang merupakan inisiasi dari pelaporan aktivitas sosial dan lingkungan perusahaan yang mengacu pada triple bottom line atau 3P (profit, people, planet). Tujuan dari pelaporan GRI adalah membantu perusahaan dalam mengungkapkan kinerja secara internal dan kinerja secara eksternal sehingga dapat meningkatkan kredibilitas dan akuntabilitas. Pedoman GRI terdiri dari prinsip untuk mendiskripsikan konten laporan CSR dan memberikan kepastian bahwa informasi yang dilaporkan berkualitas (GRI 2011b).

Pengungkapan kinerja internal dan kinerja eksternal berdasarkan standar GRI dapat dijelaskan sebagai berikut: (1) pengungkapan kinerja internal terdiri dari pengungkapan umum, pendekatan manajemen ekonomi, pendekatan lingkungan dan pendekatan sosial terhadap 
lingkungan perusahaan. (2) Pengungkapan kinerja eksternal yang terdiri dari pengungkapan umum, pendekatan manajemen ekonomi, pendekatan lingkungan, dan pendekatan sosial terhadap masyarakat atau publik.

Pendekatan secara internal menurut standar GRI merupakan tanggung jawab terhadap bagian dari manajemen perusahaan yang terdiri dari: 1 . Pengungkapan umum yang berkaitan dengan manajemen ekonomi, manajemen sosial dan lingkungan. Pengungkapan umum memaparkan profil organisasi, strategi, etika dan integritas, dan tata kelola. 2. Pendekatan manajemen ekonomi yang menekankan pada kinerja ekonomi terkait program pensiun, keberadaan pasar terkait rasio standar upah karyawan. 3. Pendekatan lingkungan yang menjelaskan hal-hal yang terkait konsumsi energi didalam perusahaan, penilaian lingkungan pemasok melalui seleksi pemasok dengan menggunakan kriteria lingkungan. 4. Pendekatan sosial yang menekankan pada mekanisme kepegawaian seperti perekrutan karyawan, hubungan tenaga kerja dan pegawai, kesehatan dan keselamatan kerja, pelatihan, keaneragaman dan kesempatan setara.

Pendekatan secara eksternal dalam standar GRI meliputi: 1. Pengungkapan umum yang memberikan informasi terkait pasar yang dilayani, inisiatif eksternal, tanggung jawab eksekutif untuk topik ekonomi lingkungan dan sosial, pengkajian topik ekonomi, lingkungan dan sosial, assurance oleh pihak eksternal, sedangkan untuk (2) pendekatan manajemen yang meliputi nilai ekonomi yang langsung dihasilkan dan didistribusikan, keberadaan pasar terkait proporsi manajemen senior yang berasal dari masyarakat lokal, (3) pendekatan lingkungan yang meliputi emisi, influen dan limbah, kepatuhan lingkungan, (4) pendekatan sosial yang terkait hak-hak masyarakat adat, masyarakat, kebijakan publik, kesehatan dan keselamatan pelanggan, privasi pelanggan, kepatuhan sosial ekonomi.

Berdasarkan penjelasan diatas peneliti tertarik untuk melakukan penelitian yang berbeda dengan penelitan sebelumnya, dimana dalam penelitian yang dilakukan Michelon et.al (2015) menggunakan pendekatan substantif, simbolik, dan menggunakan pedoman pelaporan Global Reporting Initiative (GRI) sedangkan dalam penelitian ini menggunakan empat indikator dalam GRI Indeks yang kemudian dipersentasekan untuk mengetahui intensitas dari pengungkapan CSR. Hasil dari persentase ini tentunya dapat diketahui bagaimana intensitas perbandingan praktik pengungkapan tanggungjawab sosial (CSR) pada sektor pertanian dan perkebunan di Indonesia berdasarkan standar GRI yang tercermin dalam sustainability reporting (SR). Kontribusi dari peneliti diharapkan membantu stakeholder yang membutuhkan informasi akurat dan kredibel dari laporan CSR perusahaan dan pelaporan CSR yang dilakukan perusahaan secara berkelanjutan memberikan pesan moral bahwa perusahaan memperhatikan norma ekonomi, sosial, dan lingkungan baik secara internal dan eksternal untuk kepentingan publik (masyarakat).

\section{TINJAUAN LITERATUR}

\section{Teori Legitimasi}

Ghozali dan Chariri (2007) menyatakan bahwa hal yang mendasari teori legitimacy adalah kontrak sosial antara perusahaan dengan masyarakat dimana perusahaan beroperasi dan menggunakan sumber ekonomi. Oleh karena itu, perusahaan berupaya mendapatkan legitimasi dari masyarakat dengan cara melaksanakan program- program yang sesuai dengan harapan masyarakat. Penerapan yang sesuai dengan kenyataan adalah melaksanakan program Corporate Sosial Responsibility (CSR) dan mengungkapkannya baik di dalam annual report maupun sustainability report sebagai suatu bentuk informasi yang dibutuhkan investor. Intensitas 
Jurnal Akuntansi Bisnis, Vol. 19, No. 1, Maret 2021

ISSN 1412-775X (media cetak) | 2541-5204 (media online)

pengungkapan bisa berbeda antar perusahaan meskipun dari sub sektor yang sama.

\section{Global Reporting Initiative (GRI) dan CSR}

GRI membantu perusahaan dan pemerintah di seluruh dunia untuk memahami dan mengkomunikasikan dampak pada isu-isu keberlanjutan secara kritis seperti perubahan iklim,hak asasi manusia, tata kelola dan kesejahteraan sosial. Ini memungkinkan tindakan nyata untuk menciptakan manfaat sosial, lingkungan, dan ekonomi bagi semua orang. Standar pelaporan keberlanjutan (sustainability reporting) GRI dikembangkan dengan kontribusi multi-pemangku kepentingan yang benar-benar berakar pada kepentingan publik.

Standar Pelaporan Keberlanjutan GRI (Standar GRI) adalah standar global pertama dan yang paling banyak diadopsi untuk pelaporan keberlanjutan. Sejak beridir pada tahun 1997, mayoritas organisasi yang sedanga berkembang telah mengadopsi standar GRI. Faktanya, 93\% dari 250 perusahaan terbesar di dunia melaporkan kinerja keberlanjutan mereka (KPMG Survey of Corporate Responsibility Reporting, 2017).

Industri penghasil sumber daya alam, industri manufaktur dan industri jasa merupakan industri yang memiliki skala aktivitas yang luas dan beragam serta mengalami pertumbuhan yang pesat. Pertumbuhan perusahaan yang pesat memberikan kesadaran perlunya kepedulian terhadap masyarakat. Kepedulian ini dapat menguatkan legitimasi perusahaan. Sesuai dengan peraturan UU No.40 maka kepedulian perusahaan dapat diwujudkan dalam bentuk pengungkapan Corporate Social Responsibility (CSR). Pengungkapan CSR saat ini merupakan bagian dari akuntansi sosial dan tata kelola perusahaan. Motivasi perusahaan melakukan pengungkapan CSR dikarenakan ada accruistic strategy (Lanros, 2001; Trisnawati, et al., 2011), motif simbolik-susbtantif (Michelon et.al, 2015), motif ekonomi (Hillman dan Keim, 2001), motif moral (Payne, 2002), reaksi konsumen (Mc William dan Siegel, 2010; Trisnawati, et al., 2011), mengurangi risiko bisnis perusahaan (Bourin dan Savarina, 2004; Trisnawati, et al., 2011). Artinya motivasi tersebut dapat memberikan energi positif bagi perusahaan yaitu berupa peningkatan profitabilitas sekaligus peningkatan kinerja.

Pelaksanaan pengungkapan CSR wajib dikomunikasikan kepada publik dalam bentuk laporan tahunan perusahaan. PSAK par 9, 2004 menyatakan bahwa laporan keuangan tahunan perusahaan harus mengakomodasi kepentingan pengambil keputusan. Namun praktik pengungkapan CSR umumnya bersifat sukarela, belum ada keterlibatan auditor dan belum teregulasi sehingga mengakibatkan adanya perbedaan dalam menggunakan skor SCR (Trisnawati, et al., 2012). Standar pelaporan untuk menerapkan CSR yang sudah dikenaladalah GRI (Global Reporting Initiative). GRI adalah lembaga yang menginisiasi perkembangan pengungkapan CSR dengan memakai rerangka laporan keberlanjutan serta memiliki motivasi untuk terus memperbaiki dan mengimplementasikannya di seluruh dunia. (www. Globalreporting.org). Penelitian mengenai pengungkapan CSR dengan menggunakan standar GRI telah dilakukan oleh beberapa peneliti (Ross, 2011), Amalia dan Made (2013), Aida dan Afriati (2014), Michelon et al., (2015), Heryanto dan Juliarto (2017)

\section{METODE PENELITIAN}

\section{Populasi dan Sampel}

Populasi pada penelitian ini adalah sub sektor perusahaan pertanian dan perkebunan yang terdaftar dalam www.sahamok.com dengan kriteria pemilihan sampel dengan metode purposive sampling yaitu perusahaan yang melaporkan sustainability reporting. Sebanyak enam perusahaan 
yang akan dianalisis yaitu PT. Astra Agro Lestari Tbk., PT. Eagle High Plantation Tbk., PP London Sumatera Indonesia Tbk., PT. Bukit Asam Tbk., PT. Sinar Mas Agro Resources \& Technology Tbk., dan PT. Sawit Sumbermas Sarana Tbk. Penelitian ini menggunakan jenis penelitian deskriptif analitis. Menurut Sugiono (2009) deskriptif analisis adalah mekanisme yang dilakukan untuk mendapatkan informasi dariobjek penelitian yang sudah didapat dan merupakan data sampel penelitian tanpa membuat analisis dan kesimpulan secara general. Artinya penelitian ini berfokus pada masalah yang diangkat dalam penelitian yang kemudian di tabulasi dan diolah untuk mendapatkan gambaran sehingga memperoleh kesimpulan. Sehingga metode analisis ini digunakan untuk mengetahui terkait fenomena yang terjadi saat ini. Objek penelitian ini adalah perusahaan sub sektor pertanian dan perkebunan yang terdaftar di www.sahamok.com. Jumlah perusahaan yang terdaftar sebanyak 19 sub sektor pertanian, kriteria sampel yang digunakan dalam penelitian ini adalah melaporkan sustainability reporting (SR) dari tahun 2016-2018.

Setelah ditentukan jumlah sampel maka dilakukan pencarian informasi yang berkaitan dengan index GRI dengan rerangka sustainability reporting (SR) berdasarkan dari masing-masing sektor Industri dengan melihat indikator pengungkapan umum, pendekatan manajemen (ekonomi), pendekatan manajemen (lingkungan), pendekatan manajemen (sosial). Apabila sudah dilakukan tabulasi berdasarkan indikator tersebut baru ditentukan kategori perusahaan tersebut berdasarkan interval yang ditentukan.

Instrumen penelitian ini adalah pengungkapan tanggung jawab sosial perusahaan menggunakan GRI standards dengan rerangka sustainability reporting (SR). Hasil dari sustainability reporting (SR) yang menggunakan GRI selanjutnya digunakan untuk melakukan identifikasi dengan menghitung perbandingan intensitas praktik pengungkapan CSR dalam sub sektor perusahaan pertanian dan perkebunan. Setelah itu dibuat interval intensitas berdasarkan rata-rata dari hasil identifikasi yang selanjutnya dilakukan analisis deskriptif. Tabel 1 menyajikan interval intensitas pengungkapan yang digunakan dalam analisis berikutnya.

Tabel 1. Interval Intensitas Pengungkapan

\begin{tabular}{|l|l|l|}
\hline No & $\begin{array}{l}\text { Persentase Interval } \\
\text { Pengungkapn CSR }\end{array}$ & Kategori \\
\hline 1. & $0 \%$ & Not Applied \\
\hline 2. & $1 \%-40 \%$ & Limited Disclose \\
\hline 3. & $41 \%-75 \%$ & Partially Applied \\
\hline 4. & $76 \%-99 \%$ & Well Applied \\
\hline 5. & $100 \%$ & Fully Applied \\
\hline
\end{tabular}

\section{ANALISIS DATA}

\section{Pengungkapan Umum}

Pengungkapan umum berkaitan dengan kondisi perushaan dalam menjelaskan perencanaan aktivitas bisnis, aturan-aturan dalam perusahaan, dan pihak yang terlibat. Pengungkapan umum menjelaskan kerangka aktivitas bisnis yang dilakukan perusahaan untuk mencapai target dengan memperhatikan norma ekonomi, sosial dan lingkungan. Hal initerlihat dalam profil organisasi, strategi, etika dan integritas, tata kelola, keterlibatan pemangku kepentingan, dan praktik pelaporan. Tabel 2 dibawah ini menjelaskan tingkat kepatuhan pengungkapan CSR berdasarkan 
pengungkapan umum pada tahun 2016, 2017, 2018.

Dari tabel dapat dilihat bahwa intentistas pengungkapan umum yang dilakukan oleh sektor pertanian dan perkebunan memiliki hasil yang berbeda-beda dimana pengungkapan tertinggi PT Astra Agro Lestari TBK dengan rata-rata selama tiga tahun melaporkan 49 pengungkapan dari total seharusnya 56 dan secara kategori masuk Well applied dengan persentase 87,50\%. Selanjutnya PT Sinar Mas Agro Resourse \& Technology rata-rata pengungkapan selama tiga tahun adalah 47 pengungkapan dari total seharusnya 56, secara kategori ternasuk Well apllied dengan persentase 84,52. PT Bukit Asam selama tiga tahun melaporkan 39 pengungkapan dari seharusnya 56 dan secara kategori termasuk Partially applied dengan persentase 70,24\%. Hasil dari ketiga perusahaan ini memberikan gambaran kemungkinan ketiga perusahaan ini dalam menjelaskan gambaran aktivitas terkait dengan struktur, aturan dan pelaporan dilakukan secara berkelanjutan. Sehingga bisa memberikan gambaran yang jelas kepada pihak pemangku kepentingan arah dari kebijakan yang dilakukan oleh perusahaan.

\section{Tabel 2. Tingkat Pengungkapan Umum CSR}

\begin{tabular}{|c|c|c|c|c|c|c|c|}
\hline \multirow{2}{*}{ Nama Perusahaan } & \multirow{2}{*}{$\begin{array}{l}\text { Pengung } \\
\text { kapan } \\
\text { Umum }\end{array}$} & \multicolumn{3}{|c|}{ Terpenuhi Tahun } & \multirow{2}{*}{$\begin{array}{l}\text { Rata- } \\
\text { Rata }\end{array}$} & \multirow{2}{*}{$(\%)$} & \multirow[t]{2}{*}{ Kategori } \\
\hline & & 2016 & 2017 & 2018 & & & \\
\hline $\begin{array}{l}\text { PT. Astra Agro Lestari } \\
\text { TBK(AALI) }\end{array}$ & 56 & 53 & 52 & 42 & 49 & 87,50 & Well Applied \\
\hline PT Bukit Asam Tbk (PTBA) & 56 & 32 & 42 & 44 & 39,33 & 70,24 & $\begin{array}{l}\text { Partially } \\
\text { Applied }\end{array}$ \\
\hline $\begin{array}{l}\text { PT. Eagle High Plantations } \\
\text { TBK (BWPT) }\end{array}$ & 56 & 0 & 33 & 33 & 22,00 & 39,29 & $\begin{array}{l}\text { Limited } \\
\text { Disclosed }\end{array}$ \\
\hline $\begin{array}{l}\text { PT. London Sumatra Indonesia } \\
\text { TBK (LSIP) }\end{array}$ & 56 & 0 & 35 & 35 & 23,33 & 41,67 & $\begin{array}{l}\text { Partially } \\
\text { Applied }\end{array}$ \\
\hline $\begin{array}{l}\text { PT. Sinar Mas Agro Resources } \\
\& \text { Technology TBK (SMAR) }\end{array}$ & 56 & 48 & 47 & 47 & 47,33 & 84,52 & Well Applied \\
\hline $\begin{array}{l}\text { PT. Sawit Sumbermas Sarana } \\
\text { TBK }\end{array}$ & 56 & 0 & 38 & 39 & 25,67 & 45,83 & $\begin{array}{l}\text { Partially } \\
\text { Applied }\end{array}$ \\
\hline
\end{tabular}

Intensitas pengungkapan umum untuk PT. Eagle High Plantations TBK dengan rata- rata selama tiga tahun hanya melaporkan 22 pengungkapan dari total seharusnya 56 dan secara kategori termasuk limited disclosed dengan persentase 39,29\%. Hal ini terjadi karena pada tahun 2016 perusahaan belum melakukan pengungkapan umum dan pelaporan baru mulai dilakukan dari tahun 2017 dengan intentitas terpenuhi 33 setiap tahun.Sedangkan untukPT London Sumatra Indonesia TBK meskipun rata-rata dalam tiga tahun melaporkan 23 pengungkapan dari total seharusnya 56 namun masuk kategori partially applied dengan persentase $42 \%$ dimana pengungkapan setiap tahun terpenuhi 35. Persentase dari pengungkapan umum menunjukkan secara legitimasi perusahaan tersebut berupaya untuk mengungkapkan meskipun memiliki intensitas yang berbeda-beda. 


\section{Pengungkapan pendekatan Manejemen-Ekonomi}

Keberlanjutan menajemen ekonomi merupakan aktivitas yang berkaitan dengan dampak perusahaan terhadap bagi pekerja, para pemangku kepentingan, para masyarakat dan sistem ekonomi di tingkat lokal, nasional maupun global. Pengungkapan ekonomi menjelaskan cash flow di antara pemangku kepentingan yang berbeda, dan pengaruh ekonomi utama dari perusahaan di seluruh lapisan masyarakat. Indikator manajemen ekonomi terdiri dari enam aspek yang berbeda yaitu kinerja ekonomi, keberadaan pasar, dampak ekonomi tidak langsung, praktik pengadaan, anti korupsi, dan perilakuan anti persaingan.

Tabel 3. menjelaskan tingkat kepatuhan pengungkapan CSR berdasarkan indikator manajemen ekonomi pada tahun 2016, 2017, dan 2018. Dari tabel dapat dilihat bahwa PT Astra Agro Lestari TBK memiliki tingkat kepatuhan yang sempurna yaitu 13 pengungkapan dari 13 yang seharusnya diungkapkan sehingga secara persentase dalam tiga tahun mencapai $100 \%$ termasuk dalam kategori fully applied. Sedangkan PT Bukti Asam Tbk dalam kurun waktu 3 tahun rata-rata pengungkapan 11 dari13 pengungkapan yang seharusnya dilakukan. Namun untuk PT Eagle High Plantations, PT London Sumatra Indonesia, PT Sinar Mas Agro Resources \& Technology dan PT Sawit Sumbermas Sarana rata-rata yang terpenuhi selama 3 tahun hanya 1-2 pengungkapan dari seharusnya 13 pengungkapan dengan nilai persentase 7,69\% untuk 1 pengungkapan dan $17,95 \%$ untuk 2 pengungkapan.

Tabel 3. Tingkat Kepatuhan Aspek Manajemen Ekonomi

\begin{tabular}{|c|c|c|c|c|c|c|c|}
\hline \multirow[b]{2}{*}{ Nama Perusahaan } & \multirow{2}{*}{$\begin{array}{l}\text { Kepatuhan } \\
\text { Pengungkapan } \\
\text { Manajemen } \\
\text { Ekonomi }\end{array}$} & \multicolumn{3}{|c|}{ Terpenuhi Tahun } & \multirow{2}{*}{$\begin{array}{l}\text { Rata- } \\
\text { Rata }\end{array}$} & \multirow[b]{2}{*}{$(\%)$} & \multirow{2}{*}{ Kategori } \\
\hline & & 2016 & 2017 & 2018 & & & \\
\hline $\begin{array}{l}\text { PT. Astra Agro } \\
\text { Lestari TBK(AALI) }\end{array}$ & 13 & 13 & 13 & 13 & 13,00 & 100,00 & Well Applied \\
\hline $\begin{array}{l}\text { PT Bukit Asam Tbk } \\
\text { (PTBA) }\end{array}$ & 13 & 10 & 11 & 12 & 11,00 & 84,62 & Well Applied \\
\hline $\begin{array}{l}\text { PT. Eagle High } \\
\text { Plantations TBK } \\
\text { (BWPT) }\end{array}$ & 13 & 0 & 0 & 3 & 1,00 & 7,69 & Limited Disclose \\
\hline $\begin{array}{l}\text { PT. London Sumatra } \\
\text { Indonesia TBK } \\
\text { (LSIP) }\end{array}$ & 13 & 1 & 1 & 1 & 1,00 & 7,69 & Limited Disclose \\
\hline $\begin{array}{l}\text { PT. Sinar Mas Agro } \\
\text { Resources \& } \\
\text { Technology TBK } \\
\text { (SMAR) }\end{array}$ & 13 & 3 & 2 & 2 & 2,33 & 17,95 & Limited Disclose \\
\hline $\begin{array}{l}\text { PT. Sawit } \\
\text { Sumbermas Sarana } \\
\text { TBK (SSMS) }\end{array}$ & 13 & 0 & 3 & 4 & 2,33 & 17,95 & Limited Disclose \\
\hline
\end{tabular}

Hasill ini mengindikasikan kemungkinan perusahaan yang masih dalam kategori Limited disclose dalam aktivitas manajemen ekonomi terkait kinerja ekonomi, keberadaan pasar, dampak ekonomi tidak langsung, praktik pengadaan, perilaku anti pesaing belum terlaksana sepenuhnya dan kemungkinan dikarenakan pengungkapan baru dilakukan di tahun 2017, sehingga dalam pengungkapan manajemen ekonomi ini secara kontrak sosial yang diungkapkan terkait dengan kinerja ekonomi terkait dengan nilai ekonomi yang dihasilkan dan didistribusikan, implikasi 
finansial serta risiko dan peluang lain akibat perubahan iklim dan terkait insiden korupsi yang berhasil diungkapkan.

\section{Pengungkapan Manajemen Lingkungan}

Keberlanjutan lingkungan merupakan keadaan yang menjelaskan pengaruh dampak perusahaan terhadap tanah, air, udara termasuk ekosistem biotik dan abiotik. Kategori lingkungan terdiri dari pengaruh secara internal (material, energi, dan air) dan secara eksternal (emisi, efluen dan limbah). Selain itu meliputi pengungkapan terkait keaneragaman hayati, emisi, efluen dan limbah, kepatuhan lingkungan, penilaian lingkungan pemasok.

Tabel 4 dibawah ini menyajikkan tingkat kepatuhan pengungkapan CSR berdasarkan sektor lingkungan pada tahun 2016, 2017, dan 2018. Pada tabel dapat dilihat bahwa terdapat perbedaan jumlah pengungkapan yang dilakukan oleh setiap perusahaan sehingga persentase dan kategori menjadi bermacam.macam. PT Astra Agro Lestari Tbk masih konsisten dalam pengungkapan manajemen lingkungan dengan rata-rata selama 3 tahun sebanyak 29 pengungkapan dari seharusnya 30 dengan persentase 96,67\% termasuk dalam kategori Well Applied. Sedangkan untuk PT Bukit Asam Tbk dan PT Sinar Mas Agro Resources \& Technology Tbk jumlah pengungkapan 14 dan 13 pengungkapan dari seharusnya 30 sehingga persentase kedunya diatas sama dengan $41 \%$ dengan kategori partially applied. Namun untuk PT Eagle High Plantations Tbk, PT London Sumatra Indonesia, PT Sawit Sumbermas Sarana dengan jumlah pengungkapan dibawah 9 dari seharusnya 13, sehingga kategorinya adalah limited disclose dengan persentase dibawah $25 \%$.

Tabel 4. Tingkat Kepatuhan CSR Aspek Lingkungan

\begin{tabular}{|c|c|c|c|c|c|c|c|}
\hline \multirow{2}{*}{ Nama Perusahaan } & \multirow{2}{*}{$\begin{array}{l}\text { Pengungkapan } \\
\text { Kepatuhan } \\
\text { Manajemen } \\
\text { Lingkungan }\end{array}$} & \multicolumn{3}{|c|}{ Terpenuhi Tahun } & \multirow{2}{*}{$\begin{array}{l}\text { Rata- } \\
\text { Rata } \\
\text { (Mean) }\end{array}$} & \multirow{2}{*}{$(\%)$} & \multirow{2}{*}{ Kategori } \\
\hline & & 2016 & 2017 & 2018 & & & \\
\hline $\begin{array}{l}\text { PT. Astra Agro } \\
\text { Lestari TBK(AALI) }\end{array}$ & 30 & 29 & 29 & 29 & 29,00 & 96,67 & Well Applied \\
\hline $\begin{array}{l}\text { PT Bukit Asam Tbk } \\
\text { (PTBA) }\end{array}$ & 30 & 14 & 14 & 16 & 14,67 & 48,89 & Partially Applied \\
\hline $\begin{array}{l}\text { PT. Eagle High } \\
\text { Plantations TBK } \\
\text { (BWPT) }\end{array}$ & 30 & 0 & 9 & 11 & 6,67 & 22,22 & Limited Disclose \\
\hline $\begin{array}{l}\text { PT. London } \\
\text { Sumatra Indonesia } \\
\text { TBK (LSIP) }\end{array}$ & 30 & 0 & 12 & 12 & 8,00 & 26,67 & Limited Disclose \\
\hline $\begin{array}{l}\text { PT. Sinar Mas Agro } \\
\text { Resources \& } \\
\text { Technology TBK } \\
\text { (SMAR) }\end{array}$ & 30 & 14 & 12 & 11 & 12,33 & 41,11 & Partially Applied \\
\hline $\begin{array}{l}\text { PT. Sawit } \\
\text { Sumbermas Sarana } \\
\text { TBK (SSMS) }\end{array}$ & 30 & 9 & 5 & 12 & 8,67 & 28,89 & Limited Disclose \\
\hline
\end{tabular}

Artinya limited disclose masih ditemukan dibeberapa perusahaan yang kemungkinan dikarenakan tidak semua aktivitas yang terkait dengan manajemen diungkapan oleh perusahaan. Hasil dari persentase tersebut menunjukkan secara legitimasi untuk perusahaan yang berada dalam kategori 
limited disclose dalam pengungkapan manajemen lingkungan untuk PT Eagle High Plantations Tbk belum mengungkapkan terkait dengan kepatuhan lingkungan, penilaian lingkungan pemasok. PT London Sumatra Indonesia belum mengungkapkan penilaian lingkungan pemasok, pengangkutan limbah berbahaya (efluen dan limbah), konsumsi energi di luar organisasi, material kemasan, daur ulang air, dan keaneragaman hayati.

\section{Pengungkapan Manejemen Sosial}

Keberlanjutan manajemen sosial terkait dengan pengaruh yang dimiliki perusahaan dalam suatu sistem sosial dimana perusahaan tersebut melakukan aktivitas. Kategori sosial meliputi kepegawaian, hubungan tenaga kerja dan manajemen, kesehatan dan keselamatan kerja, pelatihan, keaneragaman dan kesempatan setara, non diskriminasi, kebebasan berserikat dan perundingan kolektif, pekerjaan anak, kerja paksa atau wajib kerja, praktik keamanan, ha-hak masyarakat adat, penilaian hak asasi manusia, masyarakat, penilaian sosial pemasok, kebijakan publik, kesehatan dan keselamatan pelanggan, pemasaran dan pelabelan, privasi pelanggan, kepatuhan sosial ekonomi.

Tabel 5 dibawah ini menjelaskan tingkat kepatuhan pengungkapan CSR berdasarkan sektor sosial pada tahun 2016,2017,2018. Pada tabel tersebut dapat dilihat bahwa PT Astra Agro Lestari Tbk mempunyai tingkat kepatuhan tertinggi dengan pengungkapan yang terpenuhi rata-rata selama 3 tahun adalah 30 pengungkapan dari seharusnya 34 pengungkapan, dengan persentase 90,20\% termasuk dalam kategori well applied. Sedangkan untuk PT Bukit Asam Tbk dan PT Sinar Mas Agro Resouces \& Technology Tbk mempunyai tingkat kepatuhan pengungkapan diatas 14 dari seharusnya 34 sehingga persentasenya diatas $41 \%$ termasuk dalam kategori partially appllied. PT Eagle High Plantations Tbk dan PT London Sumatera Indonesia kepatuhan pengungkapannya masih berada dibawah 12 dari yang seharusnya 34 dengan persentase dibawah $35 \%$ dan termasuk dalam limited disclose. Hal ini kemungkinkan ada keterbatasan aktivitas yang belum diungkapkan sehingga secara legitimasi perusahaan belum secarapenuh mengungkapkan informasi yang teradapat dalam pengungkapan manajemen sosial.

\section{Tabel 5. Tingkat Kepatuhan Pengungkapan SCR Aspek Sosial}

\begin{tabular}{|c|c|c|c|c|c|c|c|}
\hline \multirow{2}{*}{ Nama Perusahaan } & \multirow{2}{*}{$\begin{array}{l}\text { Pengungkapan } \\
\text { kepatuahan } \\
\text { manajemen } \\
\text { Sosial }\end{array}$} & \multicolumn{3}{|c|}{ Terpenuhi Tahun } & \multirow{2}{*}{$\begin{array}{l}\text { Rata- } \\
\text { Rata }\end{array}$} & \multirow{2}{*}{$(\%)$} & \multirow[t]{2}{*}{ Kategori } \\
\hline & & 2016 & 2017 & 2018 & & & \\
\hline $\begin{array}{l}\text { PT. Astra Agro Lestari } \\
\text { TBK(AALI) }\end{array}$ & 34 & 31 & 30 & 31 & 30,67 & 90,20 & $\begin{array}{l}\text { Well } \\
\text { Aplied }\end{array}$ \\
\hline $\begin{array}{l}\text { PT Bukit Asam Tbk } \\
\text { (PTBA) }\end{array}$ & 34 & 21 & 26 & 26 & 24,33 & 71,57 & $\begin{array}{l}\text { Partially } \\
\text { Applied }\end{array}$ \\
\hline $\begin{array}{l}\text { PT. Eagle High } \\
\text { Plantations TBK } \\
\text { (BWPT) }\end{array}$ & 34 & 0 & 12 & 11 & 7,67 & 22,55 & $\begin{array}{l}\text { Limited } \\
\text { Disclose }\end{array}$ \\
\hline $\begin{array}{l}\text { PT. London Sumatra } \\
\text { Indonesia TBK (LSIP) }\end{array}$ & 34 & 4 & 15 & 15 & 11,33 & 33,33 & $\begin{array}{l}\text { Limited } \\
\text { Disclose }\end{array}$ \\
\hline $\begin{array}{l}\text { PT. Sinar Mas Agro } \\
\text { Resources \& } \\
\text { Technology TBK } \\
\text { (SMAR) }\end{array}$ & 34 & 14 & 18 & 14 & 15,33 & 45,10 & $\begin{array}{l}\text { Partially } \\
\text { Applied }\end{array}$ \\
\hline $\begin{array}{l}\text { PT. Sawit Sumbermas } \\
\text { Sarana TBK (SSMS) }\end{array}$ & 34 & 0 & 22 & 20 & 14,00 & 41,18 & $\begin{array}{l}\text { Partially } \\
\text { Applied }\end{array}$ \\
\hline
\end{tabular}




\section{Analisis Intensitas Pengungkapan Tahun 2016, 2017, 2018.}

Keberlanjutan bagi perusahaan merupakan suatu komitmen untuk menjaga keseimbangan kinerja di sektor ekonomi, lingkungan dan sosial kemasyarakatan di masa sekarang maupun yang akan mendatang. Tujuan dari keberlanjutan ini adalah untuk menjaga ekosistem lingkungan beserta seluruh isinya untuk kehidupan sekarang dan generasi yang akan datang agar lebih baik. Hal ini dapat dilakukan dengan perusahaan mempertahankan keberlangsungan yang menyeluruh dan berkomitmen dalam bentuk melakukan kinerja sosial keberlanjutan, perusahaan tetap menjaga dan menjadi patner yang terbaik kepada stakeholder. Tabel 6 menyajikan rata-rata tingkat kepatuhan pengungkapan CSR perusahaan tambang tahun 2016,2017, dan 2018.

Pengungkapan umum yang dilakukan oleh perusahaan meliputi pengungkapan terkait perencanaan aktivitas bisnis, aturan-aturan dalam perusahaan, dan pihak yang terlibat.Perusahaanperusahaan perkebunan dan pertanian dalam kurun waktu 3 tahun telah melaporkan aktivitas yang dilakukan secara partially applied dengan nilai persentase 61,51\%. Artinya pengungkapan umum tersebut secara pengungkapan ada yang kemungkinan diungkapkan sebagian. Namun terkait pengungkapan aktivitas CSR yang berkaitan dengan pengelolaan ekonomi, sosial, dan lingkungan terdapat hasil yang berfluktuatif. Hal ini dilihat dari nilai rata-rata untuk pengungkapan manajemen lingkungan dalam 3 tahun memiliki rata- rata persentase 50,65\%, pengungkapan manajemen sosial dalam 3 tahun memiliki rata-rata persentase 44,07 sehingga termasuk kategori partially applied. Sedangkan untuk pengungkapan manajemen ekonomi rata-rata dalam kurun waktu 3 tahun sebesar 39,32\% yang artinya termasuk dalam limited disclose.

Pengungkapan manajemen ekonomi yang termasuk dalam kategori limited disclose dikarenakan kemungkinan ada keterbatasan dalam pengungkapan CSR yang disebabkan PT Eagle High Plantations baru mulai melakukan pengungkapan ditahun 2018 dan PT London Sumatra Indonesia dalam aktivitas pengungkapan mulai dari tahun 2017-2018 hanya melakukan satu

Tabel 6. Rata-Rata Tingkat Kepatuhan Pengungkapan CSR

\begin{tabular}{|c|c|c|c|c|c|c|c|c|}
\hline No & $\begin{array}{l}\text { Persentase } \\
\text { Pengungkapan CSR } \\
\text { tahun 2016-2018 }\end{array}$ & $\begin{array}{l}\text { PT. } \\
\text { Astra } \\
\text { Agro } \\
\text { Lestari } \\
\text { TBK }\end{array}$ & $\begin{array}{l}\text { PT } \\
\text { Bukit } \\
\text { Asam } \\
\text { Tbk }\end{array}$ & $\begin{array}{l}\text { PT. } \\
\text { Eagle } \\
\text { High } \\
\text { Plantati } \\
\text { ons } \\
\text { TBK } \\
\end{array}$ & $\begin{array}{l}\text { PT. } \\
\text { London } \\
\text { Sumatra } \\
\text { Indonesia } \\
\text { TBK }\end{array}$ & $\begin{array}{l}\text { PT. Sinar } \\
\text { Mas Agro } \\
\text { Resources } \\
\& \\
\text { Technology } \\
\text { TBK }\end{array}$ & $\begin{array}{l}\text { PT. Sawit } \\
\text { Sumbermas } \\
\text { Sarana } \\
\text { TBK }\end{array}$ & $\begin{array}{l}\text { Rata- } \\
\text { Rata }\end{array}$ \\
\hline 1 & $\begin{array}{l}\text { Pengungkapan } \\
\text { Umum }\end{array}$ & 87,50 & 70,24 & 39,29 & 41,67 & 84,52 & 45,83 & 61,51 \\
\hline 2 & $\begin{array}{l}\text { Pengungkapan } \\
\text { Manajemen } \\
\text { Ekonomi }\end{array}$ & 100 & 84,62 & 7,69 & 7,69 & 17,95 & 17,95 & 39,32 \\
\hline 3 & $\begin{array}{l}\text { Pengungkapa } \\
\text { n Manajemen } \\
\text { Sosial }\end{array}$ & 96,67 & 48,89 & 22,22 & 26,67 & 41,11 & 28,89 & 44,07 \\
\hline 4 & $\begin{array}{l}\text { Pengungkapan } \\
\text { Manajemen } \\
\text { Lingkungan }\end{array}$ & 90,20 & 71,57 & 22,55 & 33,33 & 45,10 & 41,18 & 50,65 \\
\hline & Rata-Rata Total & 93,59 & 68,83 & 22,94 & 27,34 & 47,17 & 33,46 & 48,89 \\
\hline
\end{tabular}


pengungkapan yaitu terkait proses pengadaan sedangkan untuk aktivitas lain belum diungkapkan. Selain itu PT. Sinar Mas Agro Resources \& Technology baru melakukan pengungkapan di tahun 2017 dan 2018 dengan kategori pengungkapan yang terbatas dikarenakan baru mengungkapkan terkait pengadaan barang dan jasa. Pengungkapan yang dilakukan PT. Sawit Sumbermas Sarana dimulai tahun 2017 dengan kategori pengungkapan yang belum dilakukan menyeluruh dengan fokus yang sudah diungkapkan terkait sebagaian pernyataan dari kinerja ekonomi, keberadaan pasar, aktivitas dampak tidak langsung, praktik pengadaan.

Kategori lingkungan merupakan kategori yang paling utama dan dijadikan focus perusahaan untuk mendapatkan legitimasi yang kuat dari masyarakat. Lingkungan yang terjaga kelestariannya secara biotik dan abiotik tentunya dapat meningkatkan kearifan lokal daerah tersebut. Sehingga investor menjadi tertarik untuk menginvestasikan dananya. Makna yang paling penting dari manajemen lingkungan secara umum adalah adanya tanggung jawab perusahaan akan generasi di masa mendatang yang ada didalam lingkungan dimana perusahaan tersebut beraktivitas. Nilai rata-rata persentase dalam kurun waktu 3 tahun sebesar 50,65\% termasuk dalam kategori partially applied. Kondisi ini perlu dipertahankan dan lebih baik lagi apabila ditingkatkan mengingat perusahaan ini bergerak dibidang pertanian dan perkebunan.

Kategori sosial perusahaan pertanian dan perkebunan dalam kurun waktu 3 tahun rata-rata pengungkapan sosialnya sebesar $44,07 \%$. Artinya perusahaan perlu meningkatkan cakupan pengungkapan terkait pelatihan, hak-hak masyarakat adat, penilaian hak asasi manusia keterlibatan masyarakat, privasi pelanggan sehingga dapat terjalin hubungan yang harmonis.

Persentase dari pengungkapan umum, pengungkapan manajemen ekonomi,pengungkapan manajemen lingkungan, dan pengungkapan manajemen sosial menunjukkan bahwa untuk kategori fully disclosed sudah optimal dalam mengungkapkan pelaporan CSR secara kontinyu, dan konsisten. Kategori partially applied menunjukkan upaya perusahaan mengungkapkan CSR sebagai bagian dari kependulian terhadap sosial lingkungan sekaligus untuk mendapatkan legitimasi (Sayekti, 2011). Sedangkan untuk limited disclosed kemungkinan menggambarkan masih rendahnya informasi yang diungkapkan perusahaan yang dijadikan sampel dalam penelitian ini (perusahaan pertanian dan perkebunan), dimana fatimah (2015) mengungkapkan bahwa di Malaysia skor 0 masih mendominasi artinya kesadaran dalam mengungkapkan informasi masih rendah.

\section{SIMPULAN}

Penelitian ini memberikan gambaran upaya-upaya yang dilakukan perusahaan-perusahaan dalam melakukan pengungkapan aktivitas CSR berdasarkan GRI Indeks. Hasil analisis menunjukkan tingkat pengungkapan yang berbeda antara PT. Astra Agro Lestari Tbk, PT Bukit Asam Tbk, PT. Eagle High Plantations, Tbk., PT. London Sumatra Indonesia, Tbk., PT Sinar Mas Agro Resources \& Technology Tbk., dan PT. Sawit Sumbermas Sarana, Tbk. Walaupun belum sempurna, perusahaan-perusahaan tersebut tela menunjukkan upaya mereka untuk mengungkapkan pelaporan CSR berdasarkan pedoman standar pelaporan GRI Standards.

Selama kurun waktu 3 tahun, keenam perusahaan pertanian dan perkebunan memiliki ratarata total kepatuhan pengungkapan CSR mencapai $48,89 \%$. Pada pengungkapan umum rata -rata pengungkapan mencapai $61,51 \% \%$. Tingkat kepatuhan pada kategori ekonomi sosial, dan lingkungan, di industri ini memiliki tingkat kepatuhan sebesar 39,32\%, 44.07\%, dan 50,65\%.

Hasil perbandingan dalam intenstisa pengunngkapan CSR dengan berpedoman pada GRI Standards yang meliputi pengungkapan umum, ekonomi, lingkungan dan sosial, PT. Astra Agro Lestari, Tbk merupakan perusahaan pertanian dan perkebunan yang memiliki tingkat kepatuhan 
Jurnal Akuntansi Bisnis, Vol. 19, No. 1, Maret 2021

ISSN 1412-775X (media cetak) | 2541-5204 (media online)

yang paling optimal dimana nilai persentase dari seluruh kategori rata-rata dalam kurun waktu 3 tahun sebesar 93,59\% dengan kategori Well Apllied. Sedangkan PT Eagle High Plantations Tbk memiliki tingkat kepatuhan yang rendah dengan persentase $22,94 \%$ termasuk dalam kategori limited applied.

Pada pengungkapan ekonomi PT. Astra Agro Lestari, Tbk mengungkapkan seluruh poin yang harus dilaporkan sesuai GRI Standards sehingga kepatuhan mencapai 100\%. Oleh karena itu hanya PT. Astra Agro Lestari, Tbk yang memiliki tingkat kepatuhan sebesar 100\% pada pengungkapan ekonomi termasuk dalam kategori fully appllied.

PT. Astra Agro Lestari, Tbk, dan PT Bukit Asam Tbk, merupakan 2 perusahaan yang memiliki tingkat persentase kepatuhan sosial dan lingkungan yang mendekati $100 \%$ sesuai dengan GRI Standards. Nilai persentase untuk kepatuhan sosial sebesar 96,67\% untuk PT. Astra Agro Lestari, Tbk dan 84,62\% untuk PT Bukit Asam Tbk. Sedangkan persentase kepatuhan lingkungan sebesar 90,20\% untuk PT. Astra Agro Lestari, Tbk dan 71,57\% untuk PT Bukit Asam Tbk. Pengungkapan kepatuhan ekonomi dan lingkungan dari kedua perusahaan tersebut masuk dalam kategori Well Applied. Pengungkapan kategori sosial persentase untuk ketiga perusahaan yang lainnya memiliki persentase dibawah $42 \%$ sehingga termasuk dalam kategori limted disclose.

Hasil penelitian diharapkan dapat menjadi rujukan bagi perusahaan di Indonesia terutama terkait dengan praktik pelaporan CSR yang berpedoman pada Standar GRI yang terdiri dari pengungkapan umum, pengugkapan manajemen ekonomi, manajemen lingkungan dan manajemen sosial. Kajian perbandingan ini juga bisa memberikan gambaran bahwa karakteristik perusahaan yang sama belum tentu memiliki jumlah pengungkapan yang sama sehingga diharapakan perusahaan dapat melakukan evaluasi agar dapar meningkarkan kredibilitas usaha. Penelitian ini hanya dilakukan pada perusahaan perkebunan dan pertaniam di Indonesia sehingga perbedaan karakteristik perusahaan dan negara tidak dipertimbangkan dalam penelitian ini. Penelitian ini belum menghitung tingkat error yang terjadi dari proses penginputan dari masingmasing perusahaan. Selain itu, penelitian ini melakukan perbandingan pengungkapan CSR hanya berdasarkan pedoman GRI Standards

\section{DAFTAR PUSTAKA}

Abriani, D. R., S. K. Wiryono and E. Sumirat. 2012. The Effect of Good Corporate Governance And Financial Performance On The Corporate Social Responsibility Disclosure Of Telecommunication Company In Indonesia. The Indonesian Journal of Business Administration Vol. 1, No. 5,2012: 296-300.

Aida, Y. dan Afrianti. 2014. Analisis Perbedaan Pengungkapan Corporate Social Responsibilty Pada Perusahaan High Profile dan Low Profile (Studi Empiris Perusahaan Manufaktur yang Terdaftar di BEI). Jurnal Dinamika Akuntansi danBisnis, Vo.1, No.1, Maret 2014, Hal.92-100.

Amalia R dan I. M. K. Utama. 2013. Pengaruh Indikator Good Corporate Governance dan Profitabilitas Pada Pengungkapan Corporate Social Responsibility. E-Jurnal Akuntansi Universitas Udayana 3.3:65-82.

Barnea, A. and A. Rubin. 2010. A. Corporate social responsibility as a conflict between 
shareholders. J. Bus. Ethics,97, 71-86

Ban, H.J.; I.H, Jeong. 2016. Firm life cycle, corporate social responsibility, and earnings management. Korean J.Account.Res. , 21, 1-29

Brigham, E. F and J. F. Houston, 2006. Dasar-Dasar ManajemenKeuangan (alih bahasa: Ali Akbar Yulianto). Jakarta: Salemba Empat.Ghozali,

Imam, G. dan A. Chariri (2007). "Teori Akuntansi". Semarang: Badan Penerbit Universitas Diponegoro

Boediono, G.S.B. 2005. Kualitas Laba: Studi Pengaruh Mekanisme Corporate Governancedan dampak Manajemen Laba Dengan Menggunakan Analisis Jalur. Simposium Nasional Akuntansi VIII. Jogjakarta.

Bourin, G and Savarina R. 2004. Determinants of the corporate decision to disclose social information. Accounting, Auditing and Accountability Journal, 2(1), 36-51

Cespa, G. dan G. Cestone. (2007). "Corporate Social Responsibility and Managerial Entrenchment. Journal of Economics and Management Strategy. 16 (3): 741-771

Cochran, L. P. and A. Robert. 1984. Corporate Social Responsibility and Financial Performance. Academy of Management Journal, 27, 142 - 56

Derwall, J., N. Guenster, R. Bauer, K. Koedijk. 2005. The eco-e_ciency premium puzzle. Financ. Anal. J. 61, 51-63.

Fibria, E dan A. Riduwan. 2012. Pengaruh Corporate Governance Terhadap Nilai Perusahaan: Kualitas Laba Sebagai Variabel Intervening. Skripsi. Sekolah Tinggi Ilmu Ekonomi Surabaya. Surabaya.

Friedman, M. The Social Responsibility of Business Is to Increase Its Profits. 1970. N. Y. TimesMag.

Guerard, J. Is There A Cost to Being Socially Responsible in Investing?. 1997. J. Forecast. $16,475-490$

Godfrey, P., N. W. Hatch. 2007. Researching corporate social responsibility: An agenda for the 21stcentury. J. Bus. Ethics 70, 87-98.

Harahap, S. S. 2015. Analisis Kritis Atas Laporan Kuangan. Edisi 1. Rajawali Pers: Jakarta.

Hastuti, W. 2014. Pengaruh Ukuran Perusahaan, Pertumbuhan Perusahaan dan TipeIndustri Terhadap Pengungkapan Tanggung Jawab Social Perusahaan dalam Laporan Tahunan. (Studi Empiris Pada Perusahaan Manufaktur yang Listing di BEI). E-Journal Fakultas 
Ekonomi Jurusan Akuntansi Universitas Negeri Padang

Hilman, K. 2001. Corporate social disclosure by banks and finance companies: Malaysian Evidence. Corporate, Ownership and Control 1(4), 118-130.

Indraswari, G. A. Dyah dan I. B. P. Astika. 2014. Pengaruh Profitabilitas, Ukuran Perusahaan, dan Kepemilikan Saham Publik pada Pengungkapan CSR. E-Jurnal Akuntansi

Indrawati, N. 2009. Pengungkapan Corporate Social Responsibility (CSR) Dalam Annual Report Serta Pengaruh Political Visibility dan EconomicPerformance. Jurnal, 1 (1), , 111 .

Lee, H.G., G. J. Lee. 2017. A study on the efect of corporate social responsibility activities on the firm value. Korean J.Account. Res. 22, 45-74.

Jensen, M.C. W.H. Meckling. 1976. Theory of the Firm: ManagerialBehavior, Agency Cost and Ownership Structure. Journal of Financial Economics 3(4) pp: 305-360

Jo, H. and M. A. Harjoto. 2011. Corporate Governance and Firm Value: The Impact of Corporate Social Responsibility. Journal of Business Ethics,103: pp:351-383

Kiroyan, N. 2006. Good Corporate Governance (GCG) dan Corporate Social Responsibility (CSR) Adakah Kaitan di Antara Keduanya. Economics Business Accounting Review, Edisi III, September-Desember 2006, Hal.45-58

Komite Nasional Kebijakan Governance (KNKG). 2006. Pedoman Umum Good Corporate Governance di Indonesia. Jakarta.

Lanros, P, 2001.Equator principles or how I learned to stop worrying and sustainability", Impact assesment and Project Appraisal, 27 (1)

Majeed, S. T. Aziz dan S. Saleem. 2009. The Effect of Corporate Governance Elements on Corporate social responsibility (CSR) Disclosure: An Emperical Evidence From Listed Companies at KSE Pakistan.International Jorunal of Financial Studies.

Ming, C., W. S. W. Lin, \& Fengyi. 2014. Corporate Social Responsibility and Cost ofCapital: An Empirical Study of the Taiwan Stock Market. Journal of Business Ethics 125(3), 433

Nurkhin, A. 2010. Corporate GovernanceDan Profitabilitas, PengaruhnyaTerhadap Pengungkapan CSR Sosial Perusahaan. Jurnal Dinamika Akuntansi, 2(1).

Prior, D., J. Surroca, and J. Tribo. 2008. Earnings Management and Corporate Social Responsibility. Working Paper No. 06-23, Business Economics Series 06, September 2007, Universidad Carlos III de Madrid, Madrid, pp. 1-42. Diakses tanggal 12 Januari 2019 
Jurnal Akuntansi Bisnis, Vol. 19, No. 1, Maret 2021 ISSN 1412-775X (media cetak) | 2541-5204 (media online)

Porter, M.; M. Kramer. 2006. The link between competitive advantage and corporate social responsibility.Harv. Bus. Rev. 84, 78-92.

Porter, M.; M. Kramer. 2009. Creating shared value. Harv. Bus. Rev, 89, 62-77.

Rachma, D. 2016. Pengaruh Mekanisme GCG dan Pengungkapan CSR Terhadap Kinerja Keuangan. Jurnal Ilmu dan Riset Akuntansi, 5(10).

Ramdhaningsih, A. dan I. M. K. Utama. 2013. Pengaruh Indikator Good Corporateovernance dan Profitabilitas Pada Pengungkapan Corporate social responsibility. E-jurnal Akuntansi Univesitas Udayana. Bali

Robby, H. dan Juliarto. 2017. Pengaruh Corporate Social Responsibility terhadapProfitabilitas Perusahaan (Studi Empiris pada Perusahaan Manufaktur yang Terdaftar di Bursa Efek Indonesia Periode 2014-2015). E-Journal Undip, 6 (4), 1-8

Ross, W. J. 2012. Corporate Finance 9th Edition. Irwin, McGraw-Hill.

Rustiarini, N. W. 2009. Pengaruh Struktur Kepemilikan Saham pada Pengungkapan Corporate Social Responsibility. Dalam Jurnal Riset Akuntansi, 1-24

Sartono, R. A. 2010. Manajemen Keuangan: Teori Dan Aplikasi. Edisi 4 BPFE: Yogjakarta.

Sekaredi, S. 2011. Pengaruh Corporate Governance Terhadap Kinerja Keuangan Perusahaan (Studi pada Perusahaan yang Terdaftar di LQ45 Tahun 2005-2009). Thesis. Universitas Diponegoro. Semarang

Syailendra E. S. 2016. Pengaruh Leverage, Profitabilitas dan Size Terhadap Pengungkapan Corporate Social Responsibility Pada Perusahaan DI Bursa Efek Indonesia. Journal of Economic and Economic Education, 5(1), 75-89.

Trisnawati, R., M. Zulfikar dan E. Setiawati. 2014. Implementasi corporate social responsibility sebagai bentuk tanggungjawab sosial perusahaan (studi komparasi industri perbankan syariah dan konvensional di Indonesia), laporan Penelitian Unggulan Program Studi (PUPS) tahun ke-3, tidak dipublikasikan, UMS.

Trisnawati, R., W. Zulfikar dan E. Setiawati. 2017. Pengukuran dan Implementasi corporate social responsibility berdasarkan kelompok Industri di BursaEfek Indonesia, Laporan Kemajuan Penelitian Riset Unggulan Perguruan Tinggi (PINPRU), tahun ke-1, tidak dipublikasikan, UMS.

Trisnawati, R., E. Setiawati dan Wiyadi. 2016. Sustainability Reporting and Earning Management, South East Asian Journal of Contemporary Business, Economics and Law, $12,2289-1560$

WBCSD. 2017. Corporate Social Responsibility: Meeting Changging Expectations. 
http://www.wbcsd.org. Diakses Juni 2017.

Wawo, A. 2010. Pengaruh Corporate Governance dan Konsentrasi Kepemilikan terhadap Daya Informasi Akuntansi. Disampaikan dalam Simposium Nasional Akuntansi XIII. Purwokerto, 13-14 Oktober 2010.

Solihin, I. 2008. Corporate Social Responsibility from Charity to Sustainability. Jakarta: Salemba Empat

Wiagustini, N. L. P. 2010. Dasar-Dasar Manajemen Keuangan. Denpasar: Udayana University Press.

Wood, D.J., R. Jones. 1995. Stakeholder mismatching: A theoretical problem in empirical research on corporate social performance. Int. J. Organ. Anal, 3, 229-267.

Yang, H.M.; H. H. Yoon. 2015. A study on investors0 evaluation of corporate social responsibility: Using a verification model for value relevance of accounting information. Account. Inf. Rev. 33, 25-52. 